\title{
Review
}

\section{Application of Gas Foil Bearings in China}

\author{
Yu Hou *, Qi Zhao, Yu Guo, Xionghao Ren, Tianwei Lai and Shuangtao Chen
}

check for updates

Citation: Hou, Y.; Zhao, Q.; Guo, Y.; Ren, X.; Lai, T.; Chen, S. Application of Gas Foil Bearings in China. Appl. Sci. 2021, 11, 6210. https://doi.org/ 10.3390/app11136210

\section{Academic Editors:}

Terenziano Raparelli, Andrea Trivella, Luigi Lentini and Federico Colombo

Received: 30 May 2021

Accepted: 30 June 2021

Published: 5 July 2021

Publisher's Note: MDPI stays neutral with regard to jurisdictional claims in published maps and institutional affiliations.

Copyright: (c) 2021 by the authors. Licensee MDPI, Basel, Switzerland. This article is an open access article distributed under the terms and conditions of the Creative Commons Attribution (CC BY) license (https:/ / creativecommons.org/licenses/by/ $4.0 /)$.
School of Energy and Power Engineering, Xi'an Jiaotong University, Xi'an 710049, China; wheredream2012@stu.xjtu.edu.cn (Q.Z.); yu_guo@stu.xjtu.edu.cn (Y.G.); rxh0206@stu.xjtu.edu.cn (X.R.); laitianwei@mail.xjtu.edu.cn (T.L.); stchen.xjtu@mail.xjtu.edu.cn (S.C.)

* Correspondence: yuhou@mail.xjtu.edu.cn

\begin{abstract}
Gas foil bearing has been widely used in high-speed turbo machinery due to its oil-free, wide temperature range, low cost, high adaptability, high stability and environmental friendliness. In this paper, state-of-the-art investigations of gas foil bearings are reviewed, mainly on the development of the high-speed turbo machinery in China. After decades of development, progress has been achieved in the field of gas foil bearing in China. Small-scale applications of gas foil bearing have been realized in a variety of high-speed turbo machinery. The prospects and markets of high-speed turbo machinery are very broad. Various high-speed turbomachines with gas foil bearings have been developed. Due to the different application occasions, higher reliability requirements are imposed on the foil bearing technology. Therefore, its design principle, theory, and manufacturing technology should be adaptive to new application occasions before mass production. Thus, there are still a number of inherent challenges that must be addressed, for example, thermal management, rotor-dynamic stability and wear-resistant coatings.
\end{abstract}

Keywords: foil bearing; turbo machinery; gas bearing; industrial application

\section{Introduction}

Gas foil bearing has the distinct advantages of cleanliness, low friction, low temperature rise, and cost effectiveness [1]. These advantages make it applicable in most advanced turbo machinery systems, for instance, aerospace, energy and power engineering, etc. [2-4].

Compared with sliding bearing and ball bearing, gas foil bearings have a high running speed and a wider operating range, from tens of thousands rpm (round per minute) to hundreds of thousands rpm. Its power ranges from several kilowatts to more than 100 kilowatts, as shown in Figure 1. It is especially suitable for micro-small high-power density turbo machinery, such as fuel cell air compressors, turbo-expanders, oil-free turbochargers, etc. In comparison, sliding bearings are favored to be used in low-speed applications due to their oil lubricating properties, which are an important support component in large capacity power machinery [5]. As for magnetic bearings, their speed is between that of foil bearings and sliding bearings. Most are used in turbine generator, aeroengine, high-speed CNC (computer numerical control) machine tools, wind power equipment and other cases.

For gas foil bearings, their stability and reliability depend largely on elastic support. Under the elastic top foil, an elastic supporting structure provides additional damping, which conforms to the variable load and speed [6]. Through the damping effect, vibration energy can be absorbed due to Coulomb friction dissipation between the foils and bearing housing. Even if there is impact force or unstable whirl motion, the rotor maintains its stability [7].

In order to improve the bearing performance, different types of gas foil bearings have been proposed. According to the underlying elastic structure, the most-used gas foil bearings are bump foil type, multi-leaf type, protuberant type, and so on [8]. The lubrication mechanisms of a gas foil journal and thrust bearings are basically the same. Herein, a gas foil journal bearing is chosen as an illustration, shown in Figure 2. The basic 
structure of a bump foil bearing is shown in Figure 2a [9], which consists of a flexible flat foil and an elastic bump foil. The bumps of the supporting foil are evenly distributed along the circumferential direction. The top foil is stacked over corrugated foil, and both foils are fixed at one end and are free at the other end. As for multi-leaf foil bearing, it is composed of a bearing housing and several cantilever foils [10], as shown in Figure 2b. The leading edge of the cantilever foil is fixed in the bearing, while the trailing edge is freely overlapped on the next cantilever foil. The extension direction of the cantilever foil is consistent with the rotation direction of the rotor. A wire can also be used for elastic support. In the wire supporting foil bearing, a certain number of copper wires are fixed on the back of the foil, as shown in Figure 2c [11]. The rigidity of the foil element can be adjusted by changing the number of copper wires and thicknesses of the copper wires. A viscoelastic supporting gas foil bearing is another kind of foil bearing, as shown in Figure 2d. In 1999 , the Institute of Refrigeration and Cryogenics of Xi'an Jiaotong University proposed a viscoelastic supporting gas foil bearing [12]. The foil element is a combination of a metal foil and a piece of viscoelastic supporting sheet. The spring supported foil bearing is a new type of foil bearing, as shown in Figure 2e. Hunan University presented a theoretical and experimental study on a novel nested compression spring [13,14]. The stiffness and damping of the support can be adjusted by varying the number and size of springs. In the protuberant foil structure, as shown in Figure $2 \mathrm{f}$, there are multiple layers of protuberant foil between the top foil and the bearing housing [15]. The supporting foil element is composed of a top foil and two protuberant foils. In the assembly process, the bearing performance and stability of the bearing can be improved and the wear on the bearing surface is reduced due to the effective elastic pre-deformation of the protuberant foils [16,17].

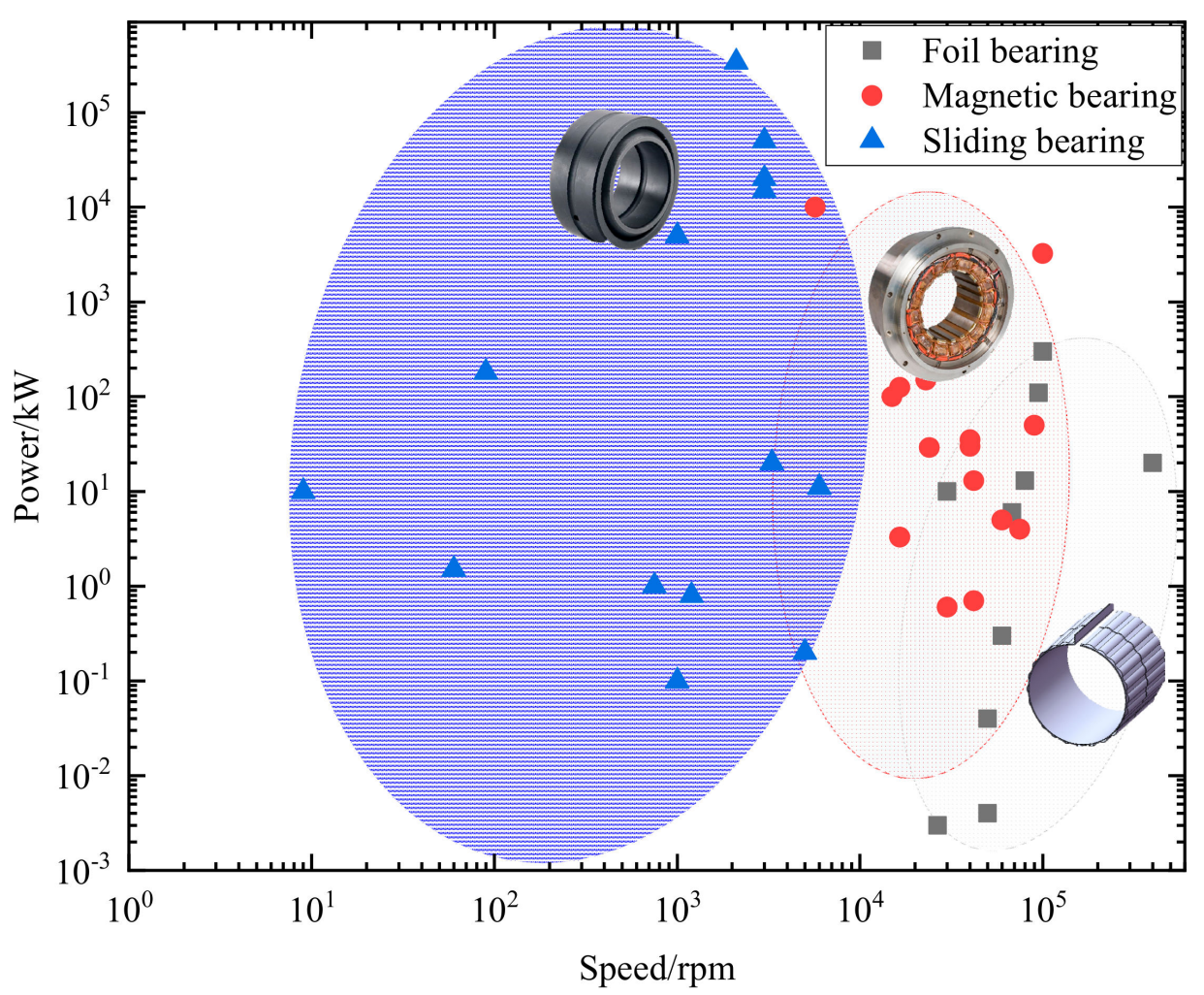

Figure 1. Application range of different kinds bearings. 


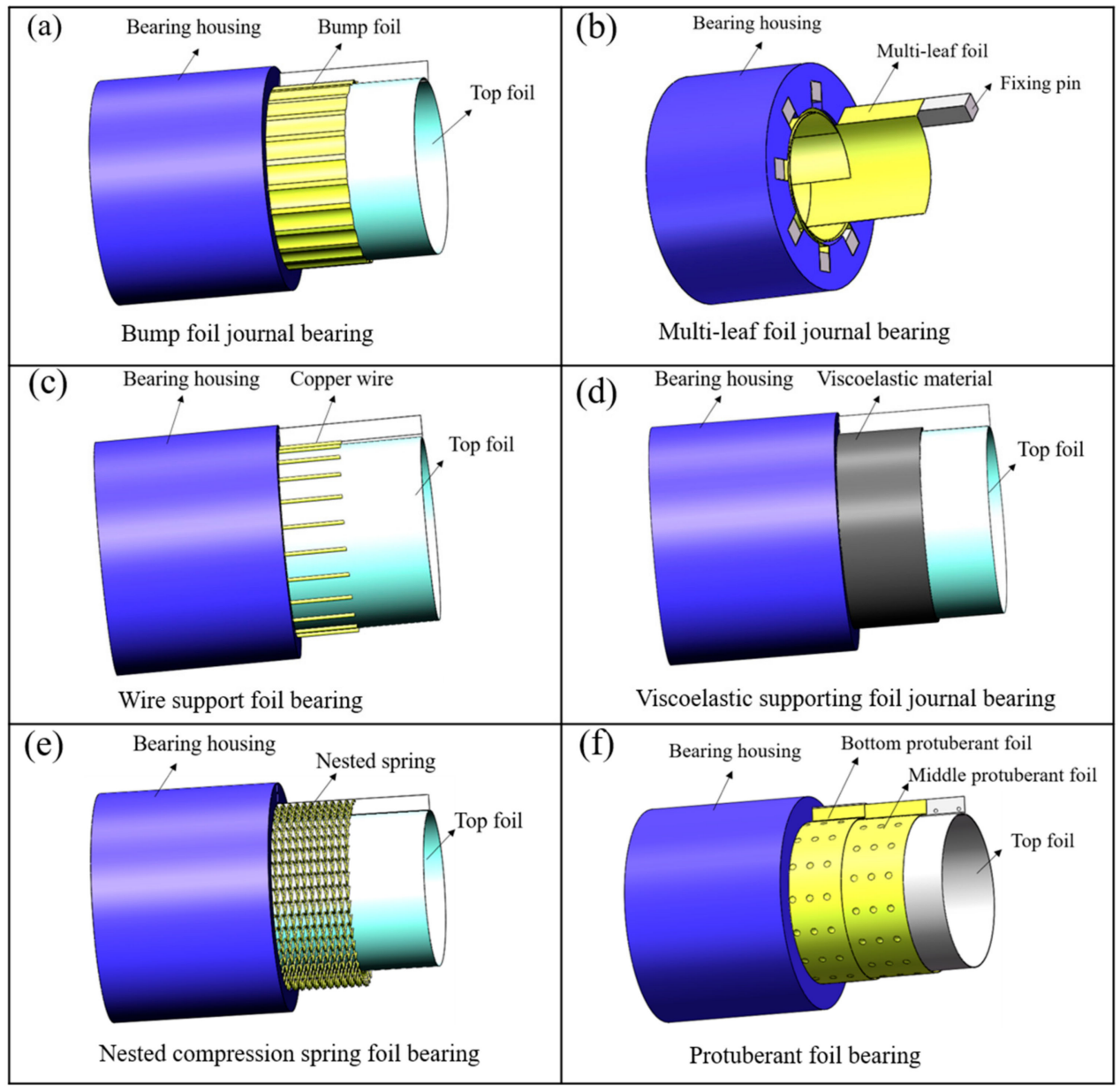

Figure 2. Typical gas foil journal bearings. (a) bump foil bearing; (b) multi-leaf foil bearing; (c) wire supporting foil bearing; (d) viscoelastic supporting gas foil bearing; (e) spring supported foil bearing; (f) protuberant foil bearing.

Before large scale industrial application of the gas foil bearing can be achieved, there are still some practical problems that should be considered. For example, gas foil bearings need to operate stably between takeoff speeds and landing speeds. During starting and stopping processes, the foil will wear poorly in the long run due to the contacting dry friction and the large friction torque. On the other hand, larger power density turbomachinery might lead to a larger axial force, which imposes harsh working requirements on the thrust bearing [18]. In addition, due to the interaction of the foil support structure and the nonlinearity, challenges still exist in accurate theoretical analyses and numerical predictions on foil bearing performance.

The research on gas foil bearings has been carried out relatively early abroad, and mainly used in micro gas turbines [19,20], turbo-expanders [21,22], turbochargers [23-25], fuel cell air compressors machines [26,27], air cycle machines [28], and other options [29]. In recent years, in order to catch up with advanced technology, gas foil bearing technology has been developing rapidly in China. In the 1970s, domestic scholars conducted research on double-row orifice hydrostatic gas journal bearings. Subsequently, a large number of theoretical and experimental studies were carried out in other forms of radial and thrust gas bearings. A series of in-depth studies were conducted in $\mathrm{Xi}^{\prime}$ an Jiaotong University and other institutions, such as, Harbin Institute of Technology, and Beijing Precision Engineering Institute Aircraft industry, etc. [30] For example, a low-temperature turboexpander using rubber-stabilized hydrostatic gas bearings was successfully developed by $\mathrm{X}^{\prime}$ an Jiaotong University in 1981. Currently, a series of theoretical and experimental research experiments on gas foil bearings has been conducted at Xi'an Jiaotong University [31], 
Hunan University [32,33], the Harbin Institute of Technology [34], Nanjing University of Aeronautics and Astronautics [35-37], the GREE company, and other institutions [38]. Although some progress has been achieved in foil bearings and their applications, a certain number of breakthroughs are still anticipated before large-scale application. In this paper, the progress of domestic gas foil bearings and their applications in high-speed turbo machinery are reviewed, which could provide a reference and guidance for further developments and applications of gas foil bearings.

\section{Applications of Gas Foil Bearings}

\subsection{Application in Low Temperature High-Speed Turbo-Expander}

The working temperature of a cryogenic expander is always lower than 120 Kelvin. In order to enlarge the mass flow rate and maintain a relatively high adiabatic efficiency, its rotor needs to run at a high speed under low temperatures. By using the gas foil bearing, the unstable whirl motion of the rotor bearing system can be suppressed and effectively attenuated. Its stability and reliability can be improved notably. In the 1990s, theoretical and experimental research on air foil bearings for turbo-expanders was initiated by the Institute of Refrigeration and Cryogenics of $\mathrm{Xi}^{\prime}$ an Jiaotong University. The rated air volume of the turbo-expander is $600 \mathrm{Nm}^{3} / \mathrm{h} @ 1.15 \mathrm{MPa}$, and it can work between $0-110 \mathrm{krpm}$ (overspeed to $150 \mathrm{krpm}$ ) according to the air supply pressure [39]. The research work on the wire support, viscoelastic support, bump foil support, protuberant support, and multi-leaf foil bearings has been carried out successively, and some progress has been made.

In China, foil bearings were first used in cryogenic turbo-expanders, and then gradually extended to other fields. In 1998, a wire support elastic structure foil bearing was first proposed [40]. In the experiment, a stable speed of $120 \mathrm{krpm}$ or more was reached, and the maximum amplitude was less than $12 \mu \mathrm{m}$. The experimental results showed that the turbo-expander ran smoothly at an overspeed of $120 \%$ at $118 \mathrm{krpm}$. In 1999, a turbo-expander supported by viscoelastic foil bearings achieved an excellent performance of $40 \%$ over-speeding at $148 \mathrm{krpm}$ [21]. The test used MoS2 powder and two methods of plating $\mathrm{Cr}$ and Tic to enhance the hardness of the foil, and over 50 start-stop performance tests were carried out. The test results showed that the surface-treated elastic foil thrust bearing had better start-stop performance and stability. The Institute of Refrigeration and Cryogenics of $\mathrm{Xi}^{\prime}$ an Jiaotong University also conducted a theoretical study on viscoelastic foil bearings [41] and compared the experimental results with wire supported foil bearings. It was found that the stiffness distribution of the viscoelastic bearings was more uniform and had a better stability during ultra-high-speed operations [42]. In 2006, considering the influence of friction, a simplified formula of structural stiffness was obtained, and the structural stiffness of bump foil bearing was analyzed [43]. By comparing two types of foil journal bearings with foil thicknesses of $0.05 \mathrm{~mm}$ and $0.07 \mathrm{~mm}$, the vibration characteristics and stability of a turbo-expander were studied. The maximum speed of the turbo-expander using 0.05-mm bump foil bearings was 93,336 rpm. For the turbo-expander using a 0.07-mm bump foil bearing, rotor whirl motion appeared when its maximum speed reached 93,161 rpm. The results showed that when the turbo-expander reached $93 \mathrm{krpm}$, the maximum amplitude of the rotor was less than $20 \mu \mathrm{m}$ [44]. In 2012, in order to analyze the feasibility of the application of protuberant foil journal bearings in a turbo-expander, another experimental study was carried out. The results showed that the maximum speed of the turbo-expander reached 99,044 rpm, and the low-frequency whirl motion was small during the entire speed-up and speed-down process [45-47]. In the total protuberant foil bearing test (both journal and thrust bearings are protuberant type), the gas foil bearing ran smoothly and had high repeatability during the operation of the turbo-expander [15]. Subsequently, the multi-leaf foil journal bearing and thrust bearing were simultaneously applied to this high-speed turbo-expander. Transient acceleration and high-speed operation tests of the rotor bearing system were carried out, and the transient characteristics and the stability of the rotor bearing system were analyzed. The experimental results showed that the starting friction torque and running resistance torque of the multi-leaf foil journal 
bearings were small, and the turbo-expander could reach 93,900 rpm. The rotor bearing system had the advantages of a smaller main frequency amplitude $(<6 \mu \mathrm{m})$ and a low frequency whirl amplitude $(<0.5 \mu \mathrm{m})$. The rotor locus was clear and had good repeatability $[48,49]$. For a cryogenic working fluid turboexpander, as shown in the Figure 3, a helium turbo-expander $(500 \mathrm{~W})$ supported by foil journal bearings was designed with a rated speed of $220 \mathrm{krpm}$. The speed could exceed the design speed by $12 \%$ in the test with a normal air temperature. In addition, a series of hydrogen turbo-expanders supported by gas foil journal bearings was also developed, with power ranging from more than 20 to $40 \mathrm{~kW}$. The turbo-expander $(39.7 \mathrm{~kW})$ with a rated speed of $74.5 \mathrm{krpm}$ was tested in an air environment. The speed could reach $60 \mathrm{krpm}$, and the amplitude was less than $0.023 \mu \mathrm{m}$. Due to their large thrust force, hydrostatic bearings are currently used as thrust bearings in hydrogen and helium turbo-expanders. Meanwhile, a carbon dioxide turbo expander with a rated speed of 125,000 rpm has been designed, as shown in Figure 4. Its rated speed could reach $80,722 \mathrm{rpm}$ in the experiment. The inlet and outlet pressures of the turbo expander were $10 \mathrm{MPa}$ and $7.3 \mathrm{MPa}$, respectively.

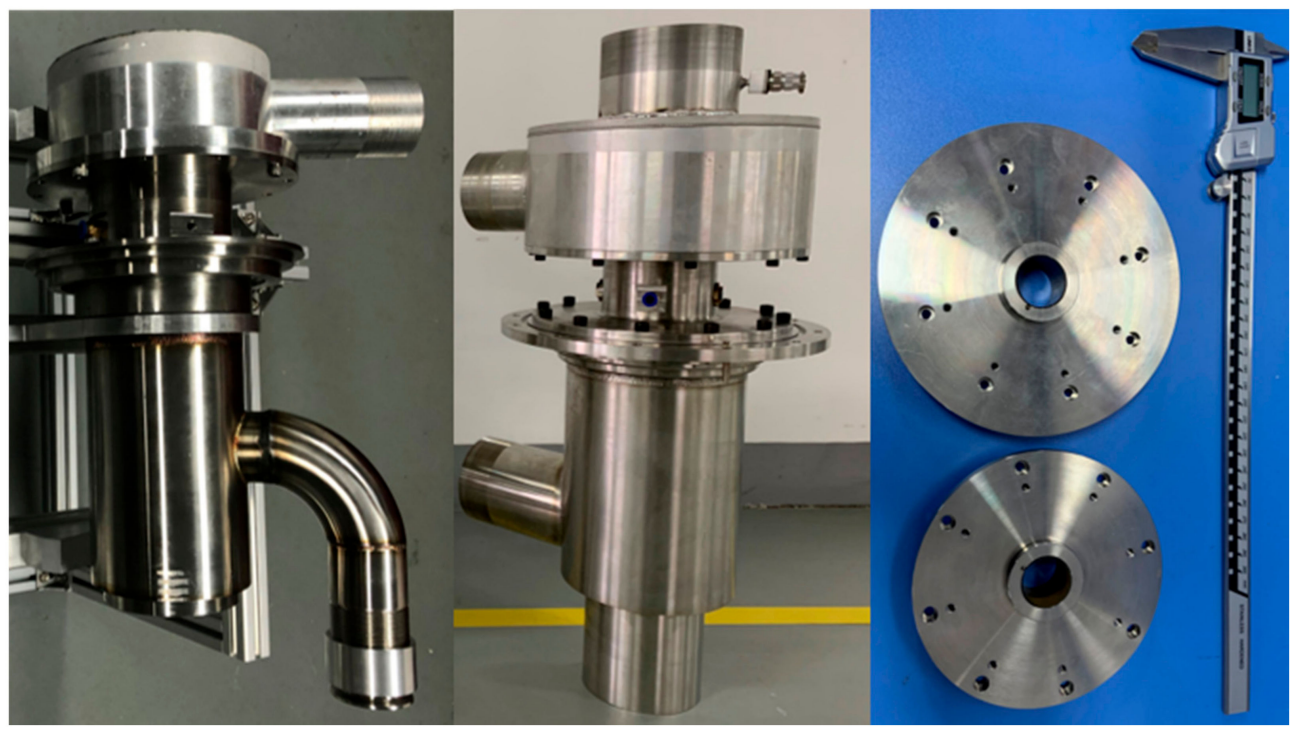

Figure 3. Helium turbo-expander and hydrogen turbo-expander by Xi'an Jiaotong University.
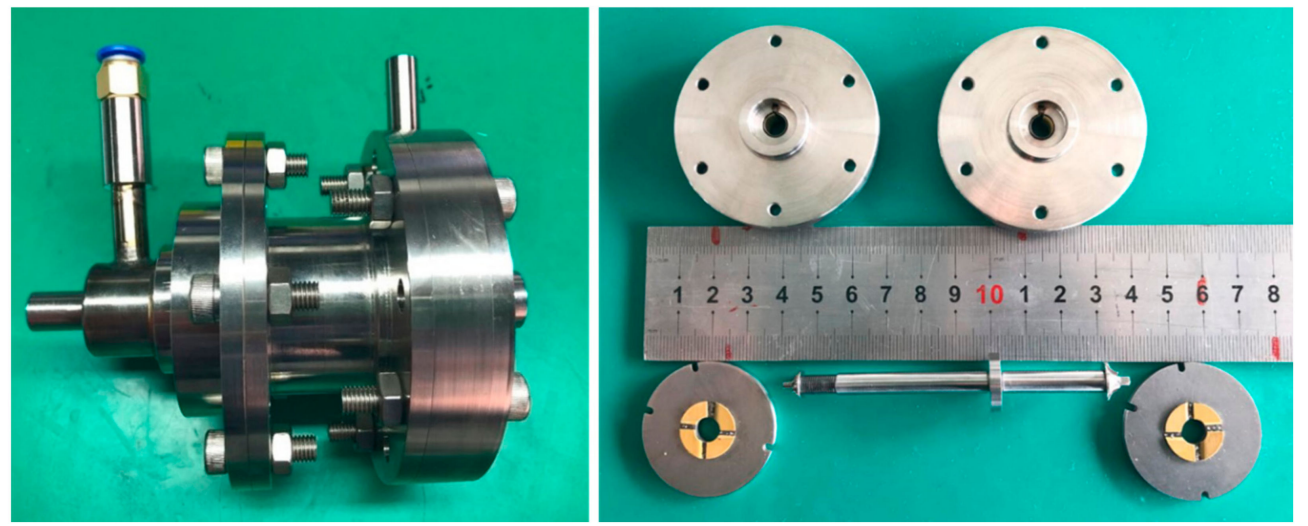

Figure 4. $\mathrm{CO}_{2}$ turbo-expander by $\mathrm{Xi}^{\prime}$ an Jiaotong University.

\subsection{Application in Air Cycle Machine (ACM)}

An air cycle machine is always used to adjust the environment in an aircraft cabin, which is the core component of the air conditioning system. It is also widely used in armored vehicles abroad for their high reliability, long service life, and oil-free characteristics. Rotor systems with gas foil bearings have become popular. At present, the main domes- 
tic research institutions engaged in ACM research are the Institute of Refrigeration and Cryogenics of Xi'an Jiaotong University, the 16th Research Institute of China Electronics Technology Group Corporation, Hunan University, and other institutions.

Since 2014, domestic research work has been carried out on the ACM system, and some progress has been made. The Institute of Refrigeration and Cryogenics of Xi'an Jiaotong University developed an airborne turbo cooler supported by gas foil bearings [50]. The structure of airborne turbo cooler is shown in Figure 5. The rotor mass is $900 \mathrm{~g}$ and the rated speed is $40 \mathrm{krpm}$. A series of tests have been carried out on its low temperature repeating start-stop and reliability performances. In vibration tests and extreme temperature $\left(-55^{\circ} \mathrm{C}\right.$ and $70^{\circ} \mathrm{C}$ ) start-up tests, its performance was better than expectations. In the tests, the coating did not peel off after a hundred start-stop and over-speed operations. In addition, a 13-kW ACM supported by gas foil bearings was designed and developed by Hunan University, and experimental research was conducted on its rotor bearing system [51]. The critical speed and unbalanced response of the ACM rotor bearing system were analyzed, and the structural parameters of the rotor bearing system were modified according to the analyses. The vibration amplitude of the prototype rotor was finally reduced to about $10 \mu \mathrm{m}$. In addition, a performance test on the turbo cooler prototype with foil bearings was conducted by Deng [52]. After 10,000 start-stop life tests and vibration tests, it was found that this machine had a good working performance. So far, the total running hours of this type of turbo cooler exceeded $1000 \mathrm{~h}$.

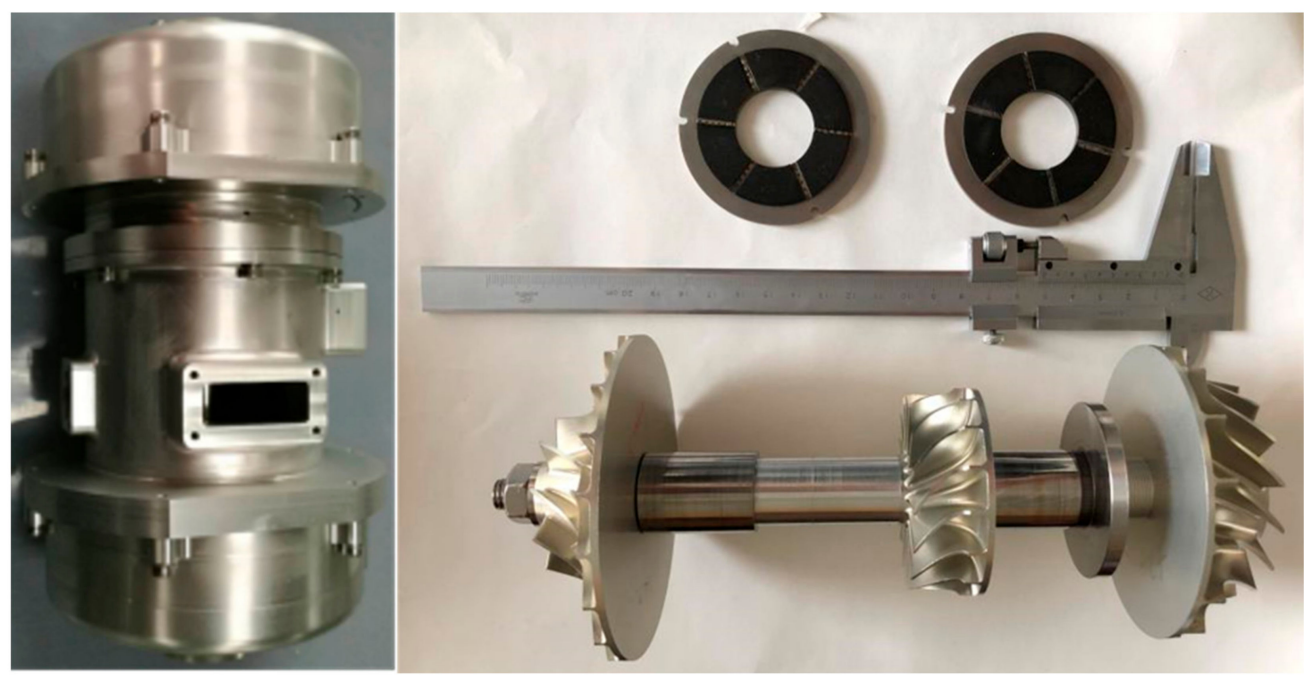

Figure 5. Airborne turbo cooler by Xi'an Jiaotong University [50].

\subsection{Application in Centrifugal Blowers}

The centrifugal blowers are important in industrial ventilation, which are widely used in many situations, such as medical, chemical, and sewage treatment. Due to the advantages of the high adaptability of the gas foil bearings, the service life and reliability of the blowers are greatly improved under extreme conditions, such as in a dusty environment. On the other hand, blower with gas foil bearings have the merits of low noise, high efficiency, and no pollution. In view of above advantages, centrifugal blowers supported by gas foil bearings have become the first choice for energy-efficient blower. Since the 1970s, foreign blower companies have tried to apply foil bearings in centrifugal blowers. By the end of the last century, highly efficient, energy-saving and highly integrated gas foil bearing blower products have come out on the market. Although domestic theoretical research on gas foil bearings has already been carried out, due to constraints such as materials and process levels, mature products are not yet available on the market. The main domestic research work in this area is the Institute of Machinery Manufacturing Technology, CAEP (China Academy of Engineering Physics) and Shijiazhuang Kingston Bearing Company. Shu X J developed a high-speed air foil bearing with a load capacity of $12.5 \mathrm{~kg}$ and tested 
the bearing performance [53]. By assembling air foil bearings, high-speed motors, and fan impellers, a prototype centrifugal blower was designed and manufactured. The centrifugal blower is shown in Figure 6. The diameter of the rotor is $80 \mathrm{~mm}$ and the maximum speed of the original machine is $30 \mathrm{krpm}$.
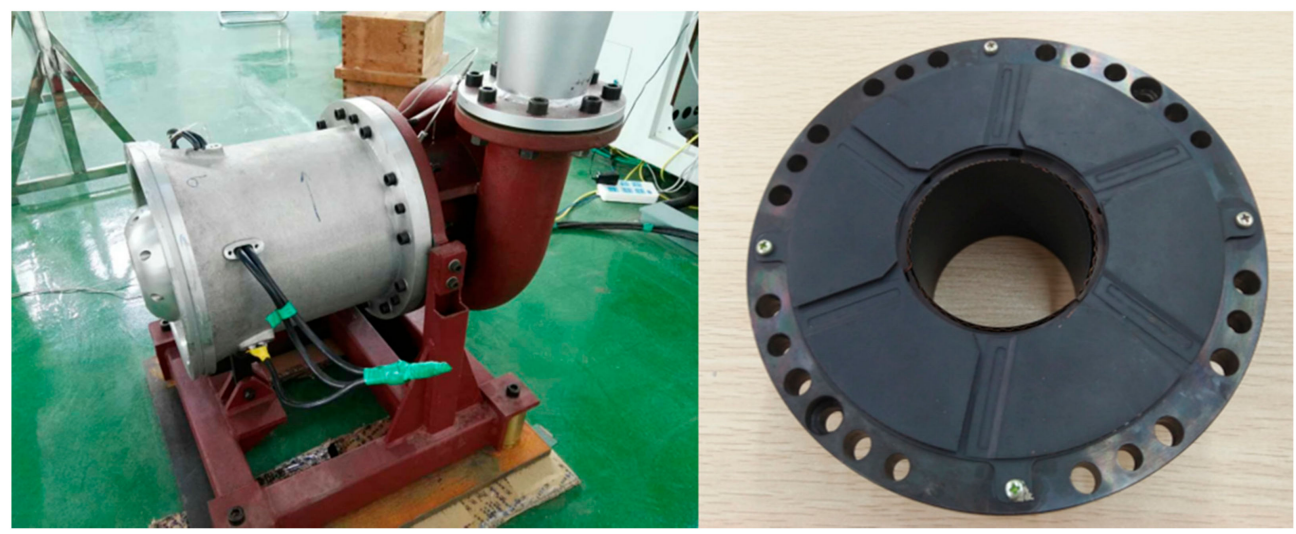

Figure 6. Centrifugal blower by the Institute of Machinery Manufacturing Technology, CAEP [53].

\subsection{Application in Oil-Free Turbocharger}

In the vehicular industry, an engine's output power can be greatly improved by increasing the air-fuel ratio of a turbocharger. Up to now, oil lubricated bearings have mostly been used in automotive turbochargers. Due to the high working temperature, there will be oil quality deterioration and coking, which may lead to catastrophic failure. These problems can be solved effectively by foil bearings. At the same time, the weight, size and complexity of the devices are greatly reduced. In addition, fuel economy and exhaust emissions are greatly improved. At present, domestic studies on turbochargers have also been carried out.

In order to improve turbocharger performance and solve problems, such as oil leakage, Hunan University conducted theoretical and experimental research on oil-free turbochargers supported by air foil bearings, as shown in Figure 7. Subsequent acceleration and deceleration test showed that the rotors exhibited large sub-synchronous vibrations at 20-60 krpm, but the sub synchronous vibration of the rotor was significantly reduced at $68 \mathrm{krpm}$. The rotor trajectory and FFT analyses showed that the main vibration of the rotor at a steady speed of $68 \mathrm{krpm}$ originated from the synchronous vibration, and the turbocharger could operate stably at $68 \mathrm{krpm}[54,55]$.

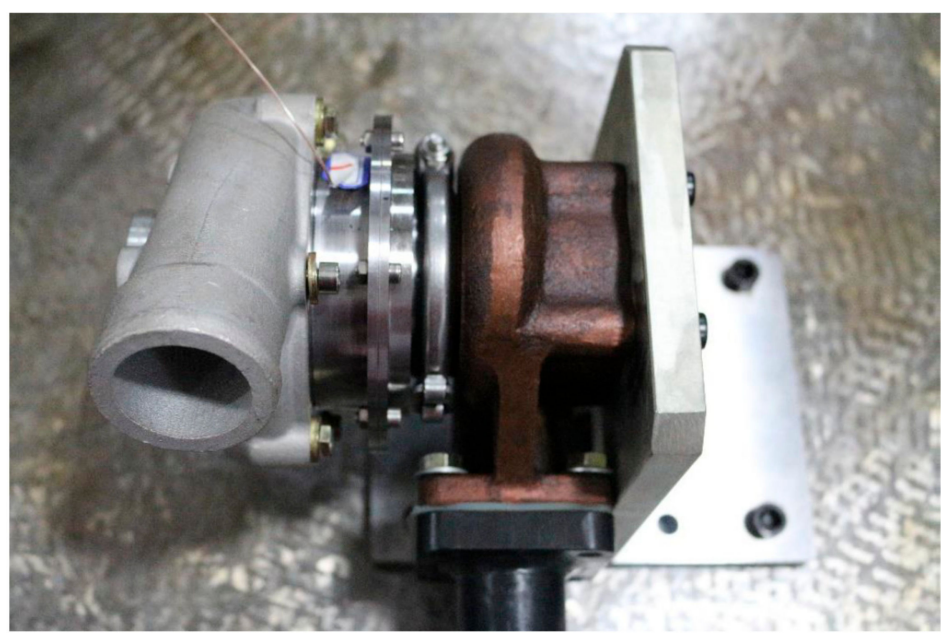

Figure 7. Oil-free turbocharger host machine by Hunan University [54]. 


\subsection{Application in High-Speed Gas Compressor}

Recently, high-speed compressors supported by gas foil bearings have become an indispensable part of fuel cell systems. Air compressors are mainly used to provide pressurized clean air. The performance of a fuel cell system is directly related to the pressure of the oxygen provided. When the air pressure is increased, the energy density of the fuel cell system can be improved and a higher output power and power performance can be obtained. Up to now, high speed air compressors with gas foil bearings have been put into use in some renewable energy automotive fuel cell systems, for example, Toyota and Honda in Japan, Garrett in the United States, etc.

After nearly ten years of hard work, prototype compressor products can be produced in China. An air compressor with a maximum speed of $120 \mathrm{krpm}(10 \mathrm{~kW})$ was developed by the Institute of Refrigeration and Cryogenics of Xi'an Jiaotong University for automotive fuel cell systems. Subsequently, prototype trial production and preliminary tests were completed. The high-speed air compressor is shown in Figure 8. The test results showed that the air compressor operated stably, and the overall technology reached the leading level in China. In addition, the State Key Laboratory for Strength and Vibration of Mechanical Structures (Xi'an Jiaotong University) developed a 11-kW, 70-krpm high-speed experimental air compressor system supported by gas foil bearings. Experiments including loss, rotor transient temperature, and critical speed were carried out and a stable operation of the system under $70 \mathrm{krpm}$ was realized [56,57]. In addition, Hunan University processed and built an oil-free high-speed air compressor experiment test rig [58]. After many test cycles, a diagram of the rotational speed and the temperature characteristics of foil bearings were drawn. Under different experimental conditions, two time-domain waveforms were used to configure the orbit of the rotor system. Meanwhile, the Dalian University of Technology designed a high-speed two-stage air compressor with gas foil bearings [59,60]. Using DyRoBes-Rotor software, the dynamic characteristics of the rotor bearing system were analyzed. The results showed that the rotor-bearing system performances had good repeatability. The maximum bearing force was $60 \mathrm{~N}$, which was much lower than the bearing capacity of $100 \mathrm{~N}$. For refrigerant compressors supported by foil bearings, a centrifugal compressor $(630 \mathrm{~kW})$ was produced by the GREE company with a rotor amplitude of less than $12 \mu \mathrm{m}$. The unit energy efficiency coefficient of performance (COP) reached 6.35, and the integrated part load value (IPLV) reached 10.15. Meanwhile, the R134a high-speed refrigerant compressor with a rated speed of $80,000 \mathrm{rpm}$ was developed by $\mathrm{Xi}^{\prime}$ an Jiaotong University, and is shown in Figure 8. Its pressure ratio is $2 \times 2$, but its size is only one third that of conventional compressors.

(a)

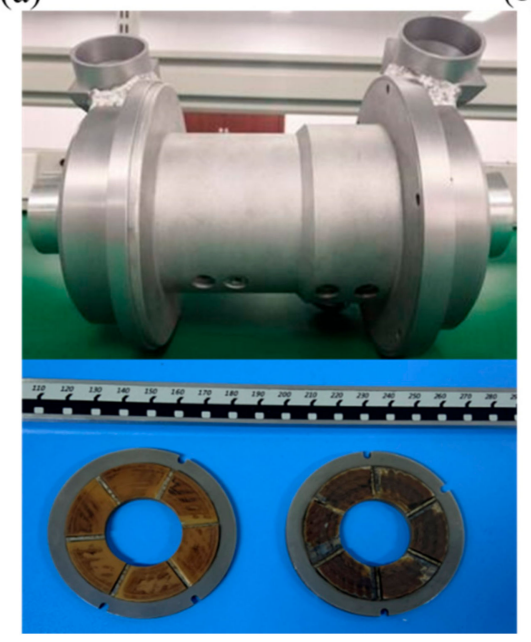

(b)

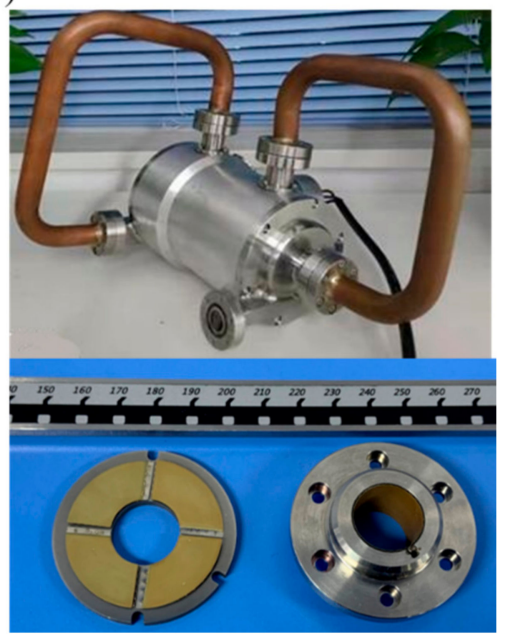

Figure 8. High-speed compressors and gas bearings by Xi'an Jiaotong University (a) air compressor; (b) refrigerant compressor. 


\section{Challenges and Prospects}

\subsection{Load Capacity of Gas Foil Bearing}

At present, domestic research on gas foil bearings is mostly focused on gas foil journal bearings, and the research content is mainly on static and dynamic performance, such as bearing capacity and stability. In a rotor bearing system, the foil thrust bearing also plays an equally important role in high-speed turbo machinery. From the perspective of the working principle, there are many similarities between the gas foil journal and trust bearings. Due to the increase in the rotational speed and the power density of turbo machinery, higher requirements are imposed on the bearing capacity and stability of gas foil thrust bearings. Compared with gas foil journal bearings, gas foil thrust bearings require a greater carrying capacity. The bearing capacity and reliability of gas foil thrust bearings have become a bottleneck for turbo machinery. Due to insufficient bearing capacity of the foil thrust bearings, turbo machinery is prone to instability and failure. Research on thrust bearings mainly focuses on experimental research. It is essential to research and develop new high-precision manufacturing and high-performance gas foil thrust bearings. In the development of foil bearing, the operation reliability and the practicability of the manufacturing process also need to be considered. At present, efforts are being made to improve the bearing capacity of journal and thrust foil bearings to $0.6 \mathrm{MPa}$ and $0.4 \mathrm{Mpa}$, respectively, in China.

\subsection{Design Criteria of Gas Foil Bearing}

Due to the diversity of industrial applications, higher requirements are put forward for the variety and performance of high-speed turbo machinery. Therefore, design criteria for gas foil bearings and appropriate foil structure parameters are crucial for their actual application; for example, the trade-off relationship between foil stiffness and Coulomb damping. In some cases, a large Coulomb damping is formed due to the high foil flexibility, which is beneficial for improving the stability of the rotor bearing system and lessening the whirl vibration amplitude. However, the large flexibility will cause a large deformation of the foil and rupture the gas film. In addition, the dynamic analysis method of the foil rotor bearing system also needs to be improved. Efforts are being made to increase the operating $\mathrm{DN}$ value of the foil bearing to $4.5 \times 10^{6} \mathrm{~mm} \cdot \mathrm{r} / \mathrm{min}$, in China.

\subsection{The Stability of Gas Foil Bearing}

The supporting force provided by the gas foil bearings is nonlinear due to the influence of geometric and structural parameters. At the same time, the high-speed rotor system also has relatively complicated dynamic characteristics, which makes stability analysis of the rotor bearing system very complicated. Larger vibration amplitudes are prone to appear in the rotor system. Subsynchronous vibration may cause serious accidents with rotating machinery. At present, a great deal of research has been carried out on subsynchronous vibration of foil bearings. However, the in-depth mechanism of the emergence of subsynchronous vibrations has not yet been found. In order to reveal the influencing mechanism of foil bearing stability, some researches could be carried out from various points of view, such as establishing a complete dynamic solution model considering gas film, foil thickness, and rotor structure, and improving experimental conditions. It is significant to analyze the formation mechanism of the non-linear bearing capacity of the gas foil bearing through experiments and theoretical calculations.

\subsection{Thermal Management of Gas Foil Bearing}

During high speed operation, a large amount of heat is generated in the foil bearing due to viscous dissipation or high-temperature working environments in some special cases, such as with micro gas turbines. The heat needs to be dissipated or discharged in time, otherwise it will cause a gas foil bearing failure. Therefore, various measures have been taken to transfer heat to prevent heat accumulation, such as processing multi-layer gap foils, adding holes, and adding heat dissipation channels on the bearing housing that 
can be used to guide cooling air. Apart from this, the development of phase coatings and supporting materials with a high heat capacity is also very beneficial for gas foil bearing thermal management. At present, a great deal of research on the thermal management of foil bearings has been carried out in China. Efforts are being made to increase the maximum operating temperature of foil bearings to $650{ }^{\circ} \mathrm{C}$.

\subsection{The Failure Protective Measures and Applications in Extreme Condition}

During the operation of the high-speed turbo machinery supported by gas foil bearings, high temperature failure caused by the accumulation of heat and the transient load in the complex environment will cause a sudden stuck of the rotor-bearing system. If the scratches are severe, it will be necessary to replace the rotor with a new one, which would cause a certain amount of economic loss and wasted time. Therefore, failure mechanisms, failure protection, and preventive measures for gas foil bearings need to be considered, which are of great significance to a stable operation. During the operation of turbo machinery, more attention should be paid to the foil temperature and rotor vibration. The temperature of a foil surface can be monitored using temperature sensors in the prevention of bearing failure due to excessively high temperatures. In addition, rotor vibration is an important parameter reflecting the operating stability of high-speed turbomachinery. The vibration displacement, velocity, or acceleration signals can be obtained by data acquisition system. When the rotor amplitude is too large, turbo machinery should be slowed down in time to prevent sudden instability and shutdown. It is a trend to equip foil bearings in aeronautical and astronautical devices. The bearing capacity of foil bearings are greatly affected by working environment, for instance in rarefied air and extreme temperature situations. At the same time, the reliability of foil bearings is required to be higher for aeronautical equipment. The challenge is how to improve the reliability, service life, and load capacity of the foil bearing. Compared with ball bearings and rolling bearings, the load capacity of foil bearings is relatively small. Due to the influence of manufacturing materials, coating technology, and turbine mechanical thermal management, the reliability and service life of foil bearings could be greatly affected.

\section{Conclusions}

The development of applications for gas foil bearings in China was summarized in this paper. Related challenges during the development process were discussed, including analyses of static and dynamic characterizations, thermal characterization, and lubricating coatings. Based on the above review and discussion, the following conclusions could be drawn:

(1) Gas foil bearing technology developed rapidly in China because of application prospects in high-speed turbo machinery. The diversity of gas foil bearing applications also put forward higher requirements on bearing design. Currently, the design criteria of gas foil bearings need to be configured for different application considerations, especially for high-performance gas foil journal and thrust bearings.

(2) Advances in foil coating technology could greatly improve the reliability and service life of turbo machinery. Research on solid lubricating coating of gas foil bearings was closely related to solid lubricating technology and coating technology. Limited by the temperature range of coating materials, friction pair selection and feasibility of manufacturing and processing, further foil coating technology research is thus needed for bearing applications.

(3) One of the major failure modes for gas foil bearing was due to thermal instability. Research is needed to develop suitable predictive tools to address this problem at the design stage. A detailed non-linear thermo-elastohydrodynamic analysis is needed, considering thermal, hydrodynamic, and structural deformation. In the design and application process, different measures should be adopted to reduce heat accumulation and bearing failure during bearing operation. 
Funding: This project was funded by the National Key R\&D Program of China (2018YFB2000100), the Na-tional Natural Science Foundation of China (51976150) and the Youth Innovation Team of Shaanxi Universities.

Institutional Review Board Statement: This paper does not involve humans or animals.

Informed Consent Statement: This paper does not involve humans or animals.

Data Availability Statement: The study did not report any data.

Conflicts of Interest: The authors declare no conflict of interest.

\section{References}

1. Samanta, P.; Murmu, N.C.; Khonsari, M.M. The evolution of foil bearing technology. Tribol. Int. 2019, 135, 305-323. [CrossRef]

2. San Andrés, L.; Ryu, K.; Kim, T.H. Thermal Management and Rotordynamic Performance of a Hot Rotor-Gas Foil Bearings System-Part I: Measurements. J. Eng. Gas Turbines Power 2011, 133, 10. [CrossRef]

3. Emerson, T. Application of Foil Air Bearing Turbomachinery in Aircraft Enviormental Contral Systems. Control Syst. 1978, 100, 111. [CrossRef]

4. Agrawal, G.L. Foil Gas Bearings for Turbomachinery; SAE Technical Paper; SAE International: Hamilton, OH, USA, 1990. [CrossRef]

5. Mokhtar, M.O.A. Floating ring journal bearings: Theory, design and optimization. Tribol. Int. 1981, 14, 113-120. [CrossRef]

6. Le Lez, S.; Arghir, M.; Frene, J. Static and Dynamic Characterization of a Bump-Type Foil Bearing Structure. J. Tribol. 2006, 129, 75-83. [CrossRef]

7. Lee, Y.B.; Kim, T.H.; Kim, C.H.; Lee, N.S.; Choi, D.H. Dynamic characteristics of a flexible rotor system supported by a viscoelastic foil bearing (VEFB). Tribol. Int. 2004, 37, 679-687. [CrossRef]

8. Agrawal, G. Foil Air/Gas Bearing Technology-An Overview. Am. Soc. Mech. Eng. 1997. [CrossRef]

9. Le Lez, S.B.; Arghir, M.; Frene, J. A New Bump-Type Foil Bearing Structure Analytical Model. In Proceedings of the ASME Turbo Expo 2007, Power for Land, Sea, and Air, Montreal, QC, Canada, 14-17 May 2007; pp. 747-757.

10. Oh, K.P.; Rohde, S.M.A. Theoretical Investigation of the Multileaf Journal Bearing. J. Appl. Mech. 1976, 43, 237. [CrossRef]

11. Wang, L.Z.; Hou, Y.; Cui, M.X.; Chen, C.Z. Damping Evaluation of Foil Bearings. J. Xi'an Jiaotong Univ. 2006, 40, 40-44. (In Chinese)

12. Chen, R.G.; Zhou, Q.; Hou, Y. Studies of self-acting journal foil bearing for miniature high speed turbo-expander. Lubr. Eng. 2010, 10, 13-17. (In Chinese)

13. Feng, K.; Liu, W.; Yu, R.; Zhang, Z.M. Analysis and experimental study on a novel gas foil bearing with nested compression springs. Tribol. Int. 2017, 107, 65-76. [CrossRef]

14. Song, J.-H.; Kim, D. Foil Gas Bearing with Compression Springs: Analyses and Experiments. J. Tribol. 2007, 129, 628-639. [CrossRef]

15. Lai, T.; Guo, Y.; Zhao, Q.; Wang, Y.; Zhang, X.Q.; Hou, Y. Numerical and experimental studies on stability of cryogenic turbo-expander with protuberant foil gas bearings. Cryogenics 2018, 96, 62-74. [CrossRef]

16. Lai, T.W.; Ma, B.; Zheng, Y.Q.; Hou, Y.; Zheng, Y.Q. Experiment investigation on stability of multi-decked protuberant foil gas journal bearings. J. Xi'an Jiaotong Univ. 2014, 3, 79-83. (In Chinese)

17. Wang, W.; Li, X.J.; Zeng, Q.; Lai, T.W.; Hou, Y. Stability analysis for fully hydraodynamic gas-lubricated protuberant foil bearings in high speed turbomachinery. J. Xi'an Jiaotong Univ. 2017, 8, 84-89. (In Chinese)

18. Łagodzinski, J.; Miazga, K.; Filipiak, I. Application of a compliant foil bearing for the thrust force estimation in the single stage radial blower. Open Eng. 2015, 5, 105-114.

19. Kozanecka, D.; Kozanecki, Z.; Tkacz, E.; Łagodziński, J. Experimental research of oil-free support systems to predict the high-speed rotor bearing dynamics. Int. J. Dyn. Control 2015, 3, 9-16. [CrossRef]

20. Lubell, D.; Dellacorte, C.; Stanford, M.; ASME. Test Evolution and Oil-Free Engine Experience of a High Temperature Foil Air Bearing Coating; American Society of Mechanical Engineers: New York, NY, USA, 2006.

21. Hou, Y.; Xiong, Y.; Chen, C.Z. Experimental study of a new compliant foil air bearing with elastic support. Tribol. Trans. 2004, 47, 308-311. [CrossRef]

22. Xiong, L.Y.; Wu, G.; Hou, Y.; Liu, L.Q.; Ling, M.F.; Chen, C.Z. Development of aerodynamic foil journal bearings for a high speed cryogenic turboexpander. Cryogenics 1997, 37, 221-230. [CrossRef]

23. Sim, K.; Lee, Y.-B.; Kim, T.H. Rotordynamic Analysis of an Oil-Free Turbocharger Supported on Lobed Gas Foil BearingsPredictions versus Test Data. Tribol. Trans. 2014, 57, 1086-1095. [CrossRef]

24. Dellacorte, C. Stiffness and Damping Coefficient Estimation of Compliant Surface Gas Bearings for Oil-Free Turbomachinery. Tribol. Trans. 2011, 54, 674-684. [CrossRef]

25. Howard, S.A. Rotordynamics and Design Methods of an Oil-Free Turbocharger. Tribol Trans. 1999, 42, 1. [CrossRef]

26. Walton, J.F.; Tomaszewski, M.J.; Heshmat, H.; ASME. The Role of High Performance Foil Bearings in Advanced, Oil-Free, High-Speed Motor Driven Compressors; Rochester: New York, NY, USA, 2003; pp. 411-417.

27. Sun, Y.H.; Cheng, W.J.; Chen, Z.F.; Zhuo, M.; Yu, L. Centrifugal Air Compressor Cooling Structure Driven by Ultra-High Speed Permanent Magnet Motor. C.N. 201310181042.5, 15 April 2015.

28. McAuliffe, C.; Dziorny, P.J. Bearing Cooling Arrangement for Air Cycle machine. U.S. Patent 5113670A, 19 May 1992. 
29. Walton, J.F., II; Tomaszewski, M.J.; Heshmat, C.A. On the Development of an Oil-Free Electric Turbocharger for Fuel Cells. In Proceedings of the 2006 ASME Turbo Expo: Power for Land, Sea \& Air, Barcelona, Spain, 1 January 2006.

30. Sun, Y.G.; Yu, X.M.; Liu, H.T. Analysis of Dynamic Stiffness and Damping of Partial Porous Aerostatic Thrust Bearings. Appl. Mech. Mater. 2009, 875, 596-600. [CrossRef]

31. Su, B.; Hou, Y.; Zhao, H.L.; Zhou, Q.; Chen, C.Z. Feasibility analysis on self-acting gas bearings of air condition system of plane. Cryogeni 2008, 3, 50-54. (In Chinese)

32. Feng, K.; Zhao, X.; Guo, Z. Design and structural performance measurements of a novel multi-cantilever foil bearing. Proc. Inst. Mech. Eng. Part C J. Mech. Eng. Sci. 2015, 229, 1830-1838. [CrossRef]

33. Feng, K.; Hu, J.; Liu, W.; Zhao, X.Y. Structural Characterization of a Novel Gas Foil Bearing with Nested Compression Springs: Analytical Modeling and Experimental Measurement. J. Eng. Gas Turbines 2016, 138. [CrossRef]

34. Li, C.L.; Du, J.J.; Yao, Y.X. Study of load carrying mechanism of a novel three-pad gas foil bearing with multiple sliding beams. Mech. Syst. Signal Process. 2020, 135. [CrossRef]

35. Luo, Y.X.; Zhang, J.Y. Analysis of gas film thermal characteristics of gas thrust bearing. Mach. Build. Autom. 2019, 48, 39-42. (In Chinese)

36. Liu, S.X.; Ma, X.Z. Dynamic Properties Analysis of Compliant Foil Aerodynamic Bearings Based on Spring Model. Appl. Mech. Mater. 2011, 86, 252-255. [CrossRef]

37. Du, K.Q.; Ma, X.Z. Research on the preparation and performances of MoS2-based lubricating coatings for gas bump foil bearings. Lubr. Eng. 2019, 44, 22-28. (In Chinese)

38. Hou, A.P.; Lin, P.C.; Wang, R.; L, J.X.; Hu, B. Performance of air-dynamic lubrication thrust bearing and experiment. J. Aerosp. Power 2018, 33, 1510-1518. (In Chinese)

39. Hou, Y.; Yang, S.J.; Chen, X.Y.; Chen, R.G.; Lai, T.W.; Chen, S.T. Application of compliant foil bearings in a cryogenic turboexpander. Journal of Harbin Eng. Univ. 2015, 4, 489-493. (In Chinese)

40. Xiong, L.Y.; Hou, Y.; Wu, G.; Wang, B.C.; Chen, C.Z. Analytical study of plate foil journal gas bearings. J. Xi'an Jiaotong Univ. 1998, 9, 56-59. (In Chinese)

41. Zhou, Q.; Hou, Y.; Cui, M.X.; Chen, C.Z. Analysis of new aerodynamic complaint foil thrust gas bearing. J. Xi'an Jiaotong Univ. 2006, 40, 1032-1035. (In Chinese)

42. Hou, Y.; Zhu, Z.H.; Chen, C.Z. Comparative test on two kinds of new compliant foil bearing for small cryogenic turbo-expander. Cryogenics 2004, 44, 69-72. [CrossRef]

43. Cui, M.X.; Hou, Y.; Wang, L.Z.; Chen, C.Z. On the calculation of structural stiffness of compliant bump foil bearing. Lubr. Eng. 2006, 5, 57-59. (In Chinese)

44. Ma, B.; Sun, W.; Lai, T.W.; Zheng, Y.Q.; Chen, S.T.; Hou, Y. Experiment study on gas lubricated hydrodynamic bump type foil bearing. J. Xi'an Jiaotong Univ. 2014, 1, 118-122. (In Chinese)

45. Zhou, Q.; Hou, Y.; Chen, R.G. Experimental research on compliant foil thrust bearings for high speed turbine expander. J. Xi'an Jiaotong Univ. 2012, 11, 49-52. (In Chinese)

46. Lai, T.W.; Zheng, Y.Q.; Chen, S.T.; Hou, Y. Experimental study on the performance of multi-decked elastic support protuberant foil gas bearing. J. Northeast. Univ. 2014, 35, 415-418. (In Chinese)

47. Lai, T.; Guo, Y.; Wang, W.; Hou, Y. Development and Application of Integrated Aerodynamic Protuberant Foil Journal and Thrust Bearing in Turboexpander. Int. J. Rotating Mach. 2017, 2017, 1-12. [CrossRef]

48. Guo, Y.; Lai, T.W.; Zhao, Q.; Chu, Y.; Chen, S.T.; Hou, Y. Experimental study of multi-leaf foil bearing inhigh-speed turbo machinery. J. Xi'an Jiaotong Univ. 2020, 54, 40-45. (In Chinese)

49. Guo, Y.; Hou, Y.; Zhao, Q.; Ren, X.H.; Lai, T.W. Application of multi-leaf foil bearings in high-speed turbo machinery. J. Adv. Mech. Des. Syst. Manuf. 2020, 14. [CrossRef]

50. Sheng, C.C.; Yang, Y.; Xie, H.T.; Gao, W.H.; Luo, G.Q.; Chen, S.T.; Hou, Y. Development and application of aerodynamic foil bearings in high-speed turbo machinery of airborne ECS. Lubr. Eng. 2020, 45, 86-90. (In Chinese)

51. Lv, P. Design and Experiment Study on Air Cycle Machine Rotor System Supported by Gas Foil Bearing. Master's Thesis, Hunan University, Changsha, China, 2017. (In Chinese).

52. Deng, W.M. Application of Air Bearing on Turbine Cooling Unit and its improvement. Equip. Manuf. Technol. 2014, 4, 140-142. (In Chinese)

53. Shu, X.J.; Xu, G.; Zheng, Y.Q.; Cui, H.L.; Lan, H. Key Technologies for centrifugal blowers with foil bearings and high speed magnet motor. Compressor Blower Fan Technol. 2017, 59, 36-42. (In Chinese)

54. Xie, Y.Q. Design and Experimental Study of an Oil Free Turbocharger. Master's Thesis, Hunan University, Changsha, China, 2015. (In Chinese)

55. Liu, W.H.; Lv, P.; Yu, R.; Feng, K. Design and experimental research of the oil-free turbocharger. J. Mech. Eng. 2018, 54, 129-136. (In Chinese) [CrossRef]

56. Lin, H.; Geng, H.; Yu, L.; Zhou, J.; Li, H. Electromechanical Analysis and Experiment for a High-speed Permanent Magnet Synchronous Compressor Supported by Elastic Foil Bearing. In Proceedings of the 2019 IEEE/ASME International Conference on Advanced Intelligent Mechatronics (AIM), Hong Kong, China, 8-12 July 2019.

57. Geng, H.P.; Cheng, W.J.; Yu, L. Cooling Structure of Motor-Driven High-Speed Centrifugal Air Compressor. CN:201110258998: A, 18 January 2012. (In Chinese) 
58. Deng, Z.H. Design and Experimental Study of an Oil-Free High Speed Compressor for Fuel Cell. Master's Thesis, Hunan University, Changsha, China, 2016. (In Chinese)

59. Jin, C.Y.; Xu, F.C.; Wu, M.L.; Fan, J.Y.; Xin, J. Calculation and Analysis of Air Bearing Centrifugal Compressor Rotor Dynamics for Fuel Cells. Automob. Parts 2020, 11, 6-9. (In Chinese)

60. Xu, F.C.; Sun, Y.; Zhang, G.H.; Liu, Z.S. Effect of bump structural friction on the performance of bump foil bearing and rotor dynamic behavior: Experimental study. Proc. Inst. Mech. Eng. Part J J. Eng. Tribol. 2019, 233, 702-711. [CrossRef] 